\title{
CAN WE MANIPULATE THE ANNUAL PATTERN OF PASTURE GROWTH?
}

T. R. 0. FIELD

Grasslands Division, DSIR, Palmerston N orth

\begin{abstract}
A bstract
The annual pattern of pasture growth rates on two Rangitaiki plains dairy farms is examined. The cyclical pattern of growth is largely determined by temperature, moisture and light levels, but modified by changes in the relative importance of individual pasture species through the year. Within this pattern, variation from year to year is least during the spring, apparently related to the flowering period of ryegrasses, and greatest in the summer-autumn period.

Animal production systems are often constrained by shortfalls in late winter-early spring feed supplies and the variability of summerautumn growth. Grazing management has a limited potential for directly modifying the pattern of pasture growth. However, application of nitrogen fertilizer can increase late winter growth rates to help overcome feed deficits, while the use of specialized pastures can ensure more reliable summer growth.
\end{abstract}

\section{INTRODUCTION}

IN a recent symposium the seasonality of pasture production was identified as imposing a major constraint on sheep, beef and dairy production systems (Rattray, 1978; Reardon, 1978; Campbell, and Bryant, 1978). Campbell and Bryant (loc. cit.) stressed both the short- and long-term effects of restricted feed supplies in the winter-early spring and summer periods on seasonal supply dairy production. Although grazing management, by rationing or conserving available feed, can reduce the impact of deficits and surpluses, improving the concordance of feed production and animal requirements at high stocking rates remains a prime farm management objective.

Three strategies to modify the annual pattern of pasture growth to achieve this objective are examined in this paper. Before these strategies are discussed, factors determining the annual growth pattern of improved grass-clover pastures are outlined using published growth rates from two Bay of Plenty dairy farms as examples.

\section{ANNUAL PATTERN OF PASTURE GROWTH}

Figure 1 shows the 'relationship between monthly temperature and pasture growth rate at the Rangitaiki Dairy Company (RPD) 


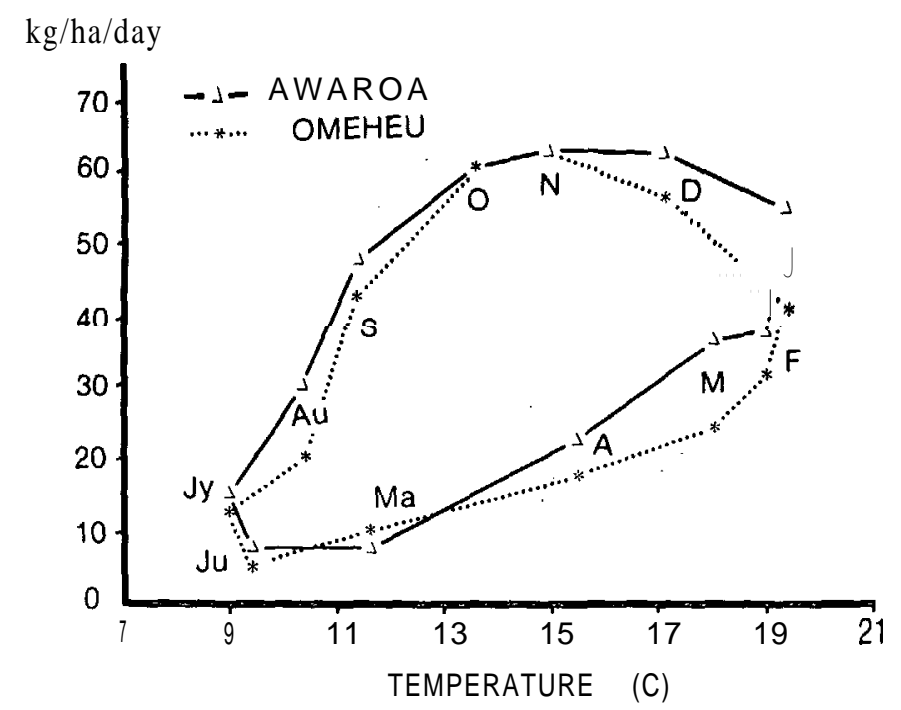

FIG. 1: Mean monthly pasture growth rates of $\mathrm{A}$ waroa and 0 meheu demonstration farms.

demonstration farms at Awaroa and Omeheu for the period June 1974 to June 1978. Growth rates, published regularly in the RPD newsletter, were obtained from weekly cuts of representative pastures of the farm. Mean temperatures were recorded at Edgecumbe, adjacent to the Awaroa farm

The pattern of pasture growth is similar for both farms, increasing in the spring and declining over the autumn-winter period with changes in temperature. Light levels, highly correlated with temperature, also contribute to this pattern.

The disparity between spring and autumn growth rates at similar temperatures can be explained on the basis of information on the annual growth pattern of the component species. In spring, ryegrass tiller numbers can be twice those in autumn, while growth rates of reproductive tillers are two to three times those of vegetative tillers under similar environmntal conditions (Hunt and Field, 1978). Sward growth rates decline after ryegrass flowering, to the lower potential of vegetative ryegrass and clover-dominant swards. Paspalum, where present, increases summer growth rates, and the plants' decline in early winter is probably responsible for low May growth rates.

Measures of the variability of pasture growth rates and temperature over the 4 years are shown in Fig. 2. The variation in temperature was similar for most months. Year-to-year varia- 


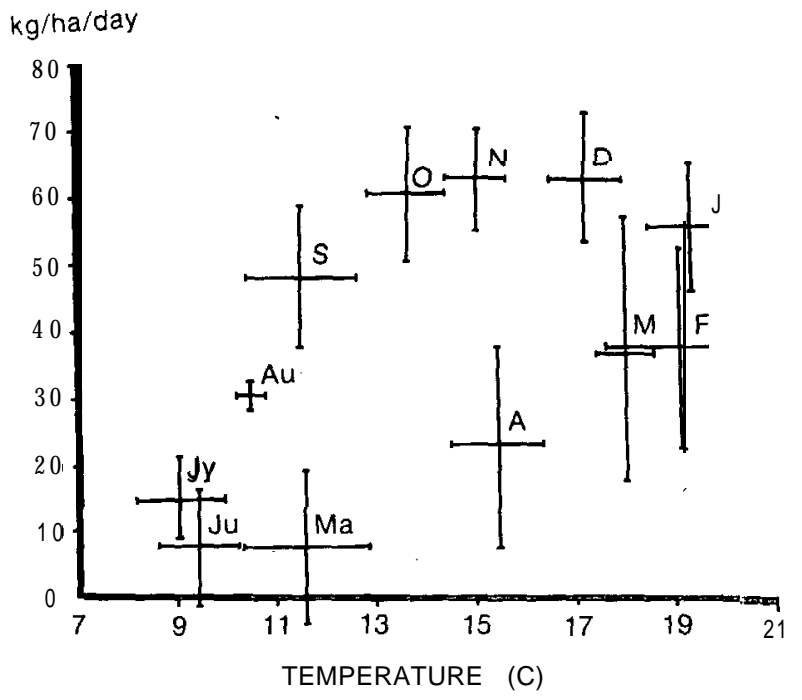

FIG. 2: Variation in pasture growth rates and temperature at Awaroa. Bars represent the standard deviation about the mean and indicate the range of the observations.

tion in growth rates in the period from July to December appeared to be related to monthly temperature variation. In proportion to mean values, variation in growth rates was least over this period. For the rest of the year, variation in growth rates did not appear to be related to temperature, and the high variability from February to April arose from variation of summer moisture regime. Negative growth rates in May and June appear to result from a rate of disappearance of paspalum faster than growth of the other species in the sward.

At high stocking rates on dairy farms, the late winter-early spring deficit identified by Campbell and Bryant (1978) is the consequence of low growth rates from May to August. The variation in year-to-year growth rates from February to April largely determines the length of lactation.

\section{CAN WE MODIFY THIS PATTERN?}

There are various strategies a grassland farmer may adopt to modify the pattern of pasture growth. Irrigation can be beneficial, and Baars and Coulter (1974) calculated that application of water would have improved summer pasture production in the Waikato 
by $25 \%$ in 15 of 43 years. Special crops such as greenfeed maize would, in many areas of the country, also fill in the frequently occurring gap in summer feed supply. Introduction of species and cultivars for early spring production and for summer-autumn growth, pasture conservation, and use of nitrogen are other complementary techniques.

It is intended here to discuss in detail: (1) altering the pattern of defoliation to improve the seasonal distribution of growth (this includes pasture conservation) ; (2) applying nitrogen fertilizer for "out-of-season" grass: (3) the introduction of different species or cultivars for improvement of summer-autumn pasture production.

\section{Grazing Management}

Grazing management is generally aimed at optimizing the degree and time at which current pasture growth is utilized, to obtain maximum animal production. However, several experiments have considered the effects of current management on future productivity, usually stressing the deleterious results of some defoliation treatments (Brougham, 1959, 1960, 1961). For example, Brougham (1960) reported that a system of grazing frequently from about 7.5 to $2.5 \mathrm{~cm}$ in the Manawatu in winter did increase pasture production in the following spring-summer period.

'At Palmerston North, six short-term mowing trials were conducted through the year to examine the effect of defoliation frequency on subsequent pasture production. By using a sickle bar mower, the intensity of defoliation was moderate $(3$ to $5 \mathrm{~cm})$, and left about 1000 to $1500 \mathrm{~kg} / \mathrm{ha}$ dry matter below cutting height. This stubble was reasonably comparable to dairy pastures. Only in spring did there appear to be scope for changing pasture production patterns through defoliation management.

In the 8 weeks from 7 September to 5 November the 'Grasslands Ariki' ryegrass/'Grasslands Huia' white clover pasture was cut either 2-weekly, 4-weekly or once at 8 weeks. On 5 November all plots were cut, and regrowth followed over the next 9 weeks. Pasture production was greater during the pretreatment period under longer cutting intervals (Table 1). In contrast, regrowth was least following the longest spell prior to the final trim. There was no difference in the continued regrowth during the following 4 weeks from 12 December to 5 January.

These data indicate that by regulating defoliation frequency a shift in the pattern of spring production can be obtained. This shift was predominantly in the ryegrass component of the sward, 
TABLE 1: PRE-TREATMENT AND REGROWTH YIELD $(\mathrm{kg} / \mathrm{ha})$ OF PLOTS CUT 2-WEEKLY, 4-WEEKLY, OR ONCE AT THE END OF THE 8:WEEK PERIOD

\begin{tabular}{ccc}
\hline $\begin{array}{c}\text { Pretreatment } \\
\begin{array}{c}\text { Cutting Interval } \\
\text { (weeks) }\end{array}\end{array}$ & $\begin{array}{c}\text { Pre-treatment Period } \\
\text { Sep. ?-N ov. 5 }\end{array}$ & $\begin{array}{c}\text { (kg/ha) } \\
\text { Regrowth Period } \\
\text { Nov. 5-Dec. 12 }\end{array}$ \\
\hline 2 & & \\
4 & 960 & 1510 \\
8 & 1410 & 1700 \\
\hline
\end{tabular}

and was probably due to the effect of defoliation on the time of elongation of reproductive tillers. In a study of perennial and short rotation (now 'Grasslands Manawa') ryegrass swards, Brougham (1961) reported that under a lax defoliation system tiller elongation in both ryegrass cultivars was delayed by continuous compared with rotational grazing. In the more frequent defoliation treatments then, the increased growth rates of the ryegrass reproductive tillers (Hunt and Field, 1978), along with some increase in tiller numbers and residual leaf area, probably produced the later peak of pasture production compared with the sward undefoliated during the pretreatment period.

In practice, rotation lengths in September-October on dairy farms are usually in the 2- to 4-week range. From the experimental results we can expect these rotation lengths to give an even pattern of pasture over the early lactation period and, as pasture production would match closely the pattern of animal requirements, result in high levels of pasture utilization (Smetham, 1973) and relatively high levels of digestibility of actively growing herbage over the late spring-early summer period. Longer spells, although increasing early pasture production, would result in less efficient utilization in early spring as well as reduced pasture growth rates in later spring.

In summary, grazing management appears to have limited potential to modify the pattern of pasture production. Even though grazing frequency can modify the distribution of pasture growth in the spring, and hard grazings in autumn and winter promote continued ryegrass production (Brougham, 1960), the main role of grazing management remains one of regulating pasture itilization.

\section{Nitrogen FERTILIZER}

Nitrogen fertilizer can increase pasture growth rates where nitrogen stress is the major factor limiting growth of the non- 
legume component of the pasture. Although grasses in grass/ legume-based pasture appear to suffer some degree of nitrogen stress at almost all times of the year (Field and Ball, 1978), fertilizer nitrogen responses increase the correspondence of pasture production and feed demand curves most markedly in early spring.

TABLE 2: GROWTH RATES OF ARIKI RYEGRASS-HUIA WHITE CLOVER PASTURES OFER THE 4-WEEK REGROWTH PERIOD FOLLOWING APPLICATION OF $0(-\mathrm{N})$ OR $45(+N) \mathrm{kg}$ N/ha

\begin{tabular}{|c|c|c|c|c|}
\hline \multirow[b]{2}{*}{ N Applied } & \multirow{2}{*}{\multicolumn{2}{|c|}{$\begin{array}{cc}\text { Pasture Growth Rates } \\
\mathbf{k g} & D M / \text { ha/day } \\
-\mathbf{N} & +N\end{array}$}} & \multicolumn{2}{|c|}{ Mean $10 \mathrm{~cm}$} \\
\hline & & & Soil & $\begin{array}{l}\text { Temperature } \\
\text { (C) }\end{array}$ \\
\hline Apr. 14 & 15.6 & 34.9 & & 11.8 \\
\hline May 13 & 21.3 & 23.0 & & 8.0 \\
\hline Jun. 11 & 10.1 & 14.1 & & 7.9 \\
\hline Jul. 10 & 12.9 & 22.9 & & 7.1 \\
\hline Aug. 4 & 25.5 & 42.4 & & 7.94 \\
\hline Sep. 2 & 72.8 & 93.0 & & 10.0 \\
\hline
\end{tabular}

From mid- July to early September in the Manawatu, soil mineral nitrogen availability appears to severely restrict pasture growth rates. Mean growth rates of Massey No. 3 dairy farm pastures were increased substantially over the 4 weeks after application of $45 \mathrm{~kg} \mathrm{~N} / \mathrm{ha}$ in July, August and September (Table 2). Growth rates in nitrogen-fertilized pasture in July were comparable to August growth rates in control pastures. Soil temperatures appeared to restrict soil nitrogen supply rather than grass growth at this time, and the application of nitrogen fertilizer advanced early season growth by up to 4 weeks.

The practical range of defoliation frequency appeared to have had little effect on the nitrogen response obtained at this time. In a trial similar to that mentioned earlier (Table 1), nitrogen response in the 8 weeks after nitrogen was applied on 11 August was similar in the two more frequent defoliation treatments (Table $3)$, even though control growth rates were reduced under the most frequent defoliation. This trial also indicated that moderate rates of nitrogen fertilizer may have some residual effect on summer clover production. Clover yield in mid-January was half that of control plots, although total production was not significantly affected.

Nitrogen fertilizer appears to have little potential for reducing feed deficits in the summer or autumn (Field and Ball, 3978). However, nitrogen applied in the autumn may improve winter feed 
TABLE 3: DRY MATTER YIELD (kg/ha) OF ARIKI RYEGRASS. HLJIA WHITE CLOVER PASTURES FOLLOWING APPLICATION OF 0 OR $45 \mathrm{~kg} \mathrm{~N} / \mathrm{ha}$ ON 11 AUGUST. PLOTS CUT AT 2-WEEKLY, 4-WEEKLY, OR ONLY ONCE OVER AN 8-WEEK REGROWTH PERIOD

\begin{tabular}{cccc}
\hline $\begin{array}{l}\text { Cutting } \\
\text { Interval } \\
\text { (weeks) }\end{array}$ & \multicolumn{2}{c}{$\begin{array}{c}\text { Yield } \\
(\mathrm{kg} / \mathrm{ha})\end{array}$} & $\begin{array}{c}\text { Efficiency } \\
(\mathrm{kg} \mathrm{DM} / \mathrm{kg} \mathrm{N})\end{array}$ \\
\hline 2 & $N 0^{2}$ & $N 45$ & 20.9 \\
4 & 2000 & 2840 & 19.8 \\
8 & 2820 & 3620 & 33.2 \\
\hline
\end{tabular}

supplies in situations where early winter temperatures do not severely restrict pasture production.

\section{Alternative Pasture Mixtures}

Perennial ryegrass and white clover form the basis of most improved lowland pastures in New Zealand agriculture. Animal production from perennial ryegrass-based pastures remains reasonably stable over a wide range of managements. However, other species, although less tlexible than perennial ryegrass, have the potential, in many farming situations, to increase the output of animal production systems.

In areas where the summer-autumn pasture production deficit encountered with ryegrass/white clover-based pastures appears to be the major constraint on dairy production, other improved cultivars can be incorporated into, or supplement, existing pasture systems. Although 'Grasslands Nui' perennial ryegrass has shown improved autumn production over 'Grasslands Ruanui',, it suffers from the same limitations as other ryegrasses under dry conditions in summer (Lancashire, 1978). However, Lancashire (loc. cit.) found that a combination of Nui and 'Grasslands Pawera' red clover had the potential to assist substantially in easing feed deficits in the summer-autumn period. The aggressive Nui combines well with Pawera to give a grass-legume mixture both relatively more stable in composition and higher in yield than a mixture of Pawera with other grasses (Harris and Hoglund, 1978; Pineiro and Harris, 1978). However, the increased Pawera production is gained at the expense of reduced cool-season Nui growth.

Under grazing by sheep, Pawera-based pastures have produced well for several years (Hay et al., 1978; W. Harris, pers. comm.) : The greater summer production is probably related to the deep- 
rootung pattern of red clover which, like lucerne, allows it to exploit a larger reservoir of soil moisture under stress (Harris and Hoglund, 1978).

The ability of lucerne to outyield ryegrass-white clover pastures over the dry summer months has been widely reported (e.g., Canterbury - O'Connor et al., 1968; Rangitikei sand country Smith and Stiefel, 1977; Taupo region - Baars et al., 1977). Growth rates of Ruanui ryegrass-Huia white clover pasture (experiment reported in Hoglund and Brock, 1978) and Wairau lucerne swards (Theobald and Ball, unpublished data) on a light soil at Palmerston North are shown in Table 4. The superiority of lucerne in the warm dry 1974-5 summer is especially marked. Overdrilling winter annuals into lucerne swards to obtain better winter-early spring production failed in two of foul years on dtyland in the absence of irrigation (Vartha and Fraser, 1978). It appears that lucerne will be used most advantageously as a substitute for, rather than be incorporated into, a grass-legume system. Despite these problems, lucerne is continuing to make a contribution to farming systems, especially dairy systems, in the drier areas of the North Island.

Other species and cultivars can also play a part in increasing summer production in dry years. Under drought conditions, paspalum has shown continued summer growth in grazing trials with sheep at Kaikohe (Lambert, 1967) and dairy cows at Ruakura (Bryant and Parker, 1970). Tall fescue has been reported to be very drought resistant in grazing trials in the Bay of Plenty (A110 and Southon, 1967), and prairie grass has been demonstrated to have a high potential for summer and autumn production under dry conditions (Lancashire, 1978). Greater use of improved New Zealand cultivars of these species in farming

TABLE 4: MONTHLY GROWTH RATES (kg/ha/day) ESTIMATED FOR WAIRAU LUCERNE AND RUANUI RYEGRASS-HUIA WHITE CLOVER PASTURES AT PALMERSTON NORTH

\begin{tabular}{lrrrrrrr}
\hline & Sep. & Oct. & Nov. & Dec. & Jan. & Feb. & Mar. \\
\hline 1974-5 & & & & & & & \\
Lucerne & 60.9 & 79.3 & 86.4 & 87.8 & 72.5 & 28.9 & 28.5 \\
Grass-clover & 70.7 & 91.3 & 66.3 & 18.4 & 10.7 & 22.6 & 31.0 \\
$\begin{array}{l}\text { 10 cm soil temp. } \\
\text { 1975-6 }\end{array}$ & 10.5 & 12.8 & 15.0 & 17.9 & 19.5 & 18.3 & 16.8 \\
Lucerne & 53.6 & 82.6 & 89.6 & 91.4 & 98.5 & 40.6 & 37.5 \\
Grass-clover & 53.3 & 66.5 & 76.6 & 62.2. & 40.1 & 33.8 & 0.8 \\
10 cm soil temp. & 9.5 & 12.7 & 13.5 & 15.4 & 17.6 & 14.8 & 15.5 \\
\hline
\end{tabular}


systems will be expected to follow further demonstration of their summer growth potential and definition of their management requirements.

\section{CONCLUSIONS}

1. Pasture management has a limited potential for modifying the climatically determined pattern of pasture growth. However, frequent, relatively intensive utilization in the spring will probably result in better pasture growth into early summer.

2. Nitrogen fertilizer will increase late winter-early spring growth rates consistently, when environmental conditions limit ryegrass growth through soil nitrogen supply.

3. Deep-rooted legumes such as Pawera red clover and lucerne can reduce the variability of summer-autumn rates.

\section{ACKNOWLEDGEMENTS}

The assistance of D. C. Anderson in making available R.P.D. demonstration farm pasture production data, and of R. Ball, J. Brock, J. Hoglund and P. Theobald, of 'Grasslands Division, in giving access to unpublished data, is gratefully acknowledged.

\section{REFERENCES}

Allo, A. V.; Southon, T., 1967. Proc. N.Z.. Grassld Ass., 29: 128-33.

Baars, J. A.; Coulter, J. D., 1974. Ibid., 35: 197-203.

Baars, J. A.; Radcliffe, J. E.; Brunswick, L. F. C., 1977. Ibid., 39: 79-85.

Brougham, R. W., 1959. N.Z. $/ l$ agric. Res., 2: 1232-48. 1960. Ibid., 3: 125-36. 1961. Ibid., 4: 516-22.

Bryant, A. M.; Parker, O. F., 1970. Proc. Ruakura Fmrs' Conf.: 123-34.

Campbell, A. G.; Bryant, A. M., 1978. Proc. Agron. Soc. N.Z., 8: 115-7.

Field, T. R. O.; Ball, R., 1978. ibid.. 8: 129-33.

Harris, W.; Hoglund, J. H., 1978. Proc. 13th Int. Grassld Congr. (in press).

Hay, R. J. M.; Kelly, R. W.; Ryan, D. L., 1978. Proc. N.Z. Grassld Ass., 38: $246-52$.

Hoglund, J. H.; Brock, J. L., 1978. N.Z. $J$ agric. Res., 21: 73-82.

Hunt, W. F.: Field, T. R. O., 1978. Ibid., 38: 104-13.

Lambert, J. P., 1967. Ibid., 29: 78-86.

Lancashire, J. Ä., 1978. Proc. Agron. Soc. N.z. 8: 123-8.

O’Connor, K. F.; Vartha, E. W.; Belcher, R. A., 1968. Proc. N.z. Grassld Ass., 30: 50-63.

Pineiro, J.; Harris, W., 1978. N.Z. Jl agric. Res., 21: 83-92.

Rattray. P. V., 1978. Proc. Agron. Soc. N.Z., 8: 103-S.

Reardon, T. F., 1978. Ibid.: 109.14.

Smetham, M. L., 1975. Proc. N.Z. Grassld Ass., 37: 91-103.

Smith, R. G.; Stiefel, W., 1977. Ibid., 39: 61-9.

Vartha, E. W.; Fraser, T.' J., 1978. N.Z. Il exp. Agric., 6: 195-200. 